\title{
High output heart failure in a young woman secondary to massive arteriovenous malformations from a uterine tumor
}

\author{
Hafez Mohammad Ammar Abdullah (D) , Tony Oliver, Randall Lamfers, \\ Smitha Narayana Gowda
}

Internal Medicine, University of South Dakota Sanford School of Medicine, Sioux Falls, South Dakota, USA

Correspondence to Dr Hafez Mohammad Ammar Abdullah;

ammar.abdullah@usd.edu

Accepted 29 January 2020

\section{DESCRIPTION}

A 30-year-old woman with no significant medical history, presented with subacute onset dyspnea for 1 month. At presentation, her physical examination revealed tachycardia, bilateral lung crackles and a faint S3 on chest examination. Abdominal examination showed lower abdominal distention with an audible bruit. Laboratory tests showed a normal complete blood cell count, basic metabolic panel and thyroid stimulating hormone. Liver function tests showed a total bilirubin of $2.1 \mathrm{mg} / \mathrm{dL}$, with normal transaminases. Brain natriuretic peptide was $>2000 \mathrm{pg} / \mathrm{mL}$. An ECG revealed sinus tachycardia. CT of the chest revealed cardiomegaly and bilateral pleural effusions (figure 1). The patient was given intravenous lasix which improved her symptoms initially. She had an echocardiogram that showed a left ventricular ejection fraction of $60 \%$. An MRI of the abdomen was performed due to the presence of an abdominal bruit. It showed massively dilated blood vessels in the uterus that resulted in large uterine arteriovenous malformations and high output heart failure (figure 2). The patient subsequently had a total abdominal hysterectomy after failed endovascular embolisation of the uterine vessels. Pathology was positive for gestational trophoblastic disease. She subsequently received chemotherapy and immunotherapy. Her heart failure completely resolved after the hysterectomy.

High output cardiac failure is an uncommon cause of heart failure. Various physiologic, pathologic and iatrogenic aetiologies can lead to this.

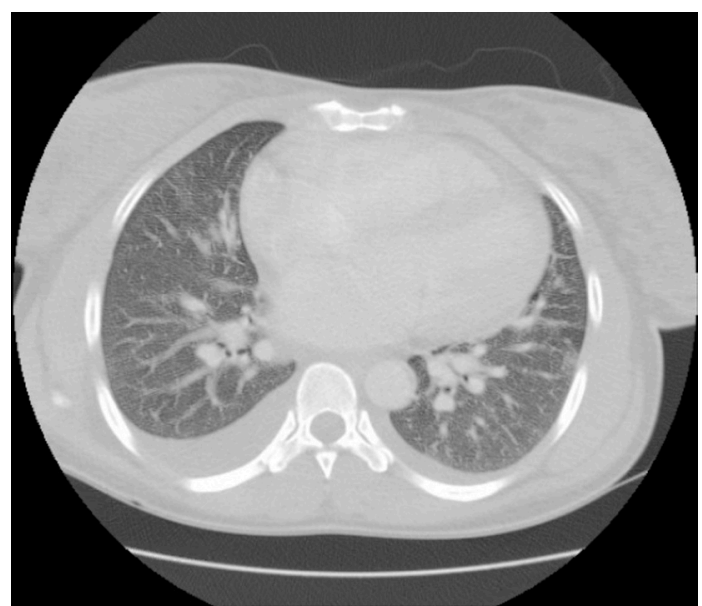

Figure $1 \mathrm{CT}$ chest showed effusions and cardiomegaly.

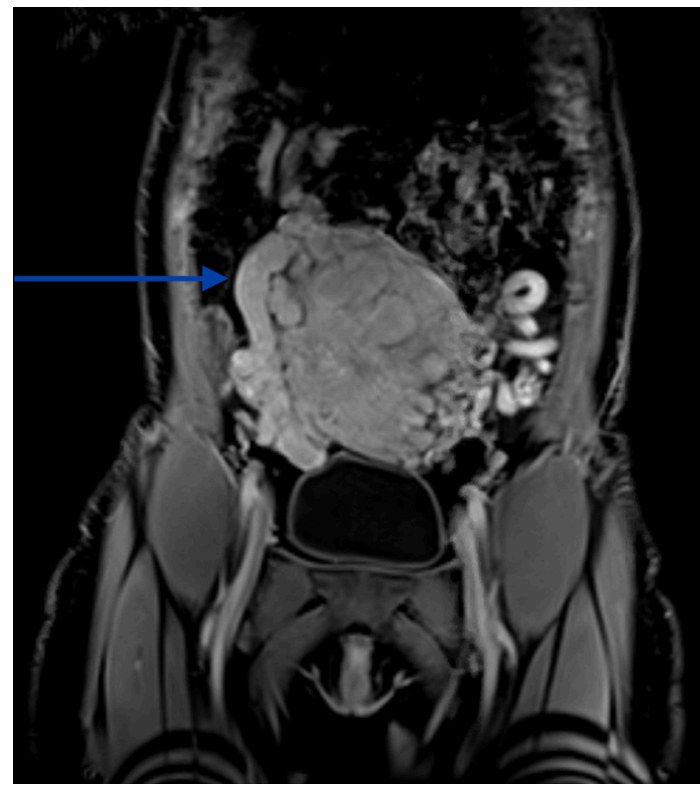

Figure 2 MRI abdomen showed abnormal serpentine uterine and parametrial vessels (arrow) that mostly replaced the uterus. These enhance in both the arterial and venous segments in the arterial phase. This is consistent with massive uterine arteriovenous malformations.

Physiological causes include pregnancy, fever and illness. Pathological causes include morbid obesity, liver disease, arteriovenous shunts, Lung diseases and myeloproliferative disorders. ${ }^{1}$ Iatrogenic causes include iatrogenic AV fistulas, pulmonary vasodilators and ionotropic medications. High output cardiac failure from AV fistulas results from the shunting of blood directly to low-pressure veins bypassing the capillary beds. There is a compensatory increase in the stroke volume, heart rate and plasma volume. ${ }^{1}$ This may result in sympathetic

\section{Learning points}

Arteriovenous malformations are a rare cause of heart failure. They should be considered as a differential especially if the patient appears otherwise healthy.

- High output heart failure can be managed easily with treating the underlying cause of the heart failure. 
activation of the renin-angiotensin axis with resultant elevated renovascular resistance and chronic salt and water retention leading to ventricular enlargement or dilatation in the long term. ${ }^{2}$ The diagnosis is based on clinical features of heart failure and identification of an AV fistula. Management includes volume status optimisation and correcting the fistula.

Contributors HMAA and TO were responsible for writing the discussion part, while RL and SNG were responsible for writing the figure legends and editing the pictures.

Funding The authors have not declared a specific grant for this research from any funding agency in the public, commercial or not-for-profit sectors.
Competing interests None declared.

Patient consent for publication Obtained.

Provenance and peer review Not commissioned; externally peer reviewed.

\section{ORCID iD}

Hafez Mohammad Ammar Abdullah http://orcid.org/0000-0002-8261-6997

\section{REFERENCES}

1 Reddy YNV, Melenovsky V, Redfield MM, et al. High-Output heart failure: a 15-year experience. J Am Coll Cardiol 2016;68:473-82.

2 Anand IS. High-Output heart failure revisited. J Am Coll Cardiol 2016;68:483-6.

Copyright 2020 BMJ Publishing Group. All rights reserved. For permission to reuse any of this content visit

https://www.bmj.com/company/products-services/rights-and-licensing/permissions/

BMJ Case Report Fellows may re-use this article for personal use and teaching without any further permission.

Become a Fellow of BMJ Case Reports today and you can:

- Submit as many cases as you like

- Enjoy fast sympathetic peer review and rapid publication of accepted articles

- Access all the published articles

Re-use any of the published material for personal use and teaching without further permission

\section{Customer Service}

If you have any further queries about your subscription, please contact our customer services team on +44 (0) 2071111105 or via email at support@bmj.com.

Visit casereports.bmj.com for more articles like this and to become a Fellow 